\title{
Antimicrobial Agent Preference for the Diagnosis of Acute Tonsillopharyngitis in Family Practice: Guidelines or Personal Choices?
}

\author{
Aile Hekimliğinde Akut Tonsillofarenjit Tanısında Antimikrobiyal Ajan Tercihi; \\ Kılavuzlar mı, Kişisel Tercihler mi?
}

Fatma İşli', Mesil Aksoy' , Ali Alkan'1, Ateş Kara²

${ }^{1}$ Turkish Medicines and Medical Devices Agency of the Ministry of Health, Ankara, Turkey

${ }^{2}$ Department of Pediatric Infectious Diseases, Hacettepe University School of Medicine, Ankara, Turkey

\begin{abstract}
Objective: While acute otitis media is the most important reason of antibiotic use in infancy and early childhood, acute tonsillopharyngitis is the main reason of antibiotic use in school-age children and adolescents. When it is considered that the unwanted effects of antimicrobial agent use rise to prominence especially today, antibiotics are recommended to be used in absolute necessity and in the most constricted efficiency range. This study aimed at examining the distributions of antimicrobial agents prescribed with the diagnosis of acute tonsillopharyngitis between January 1, 2012 and December 31, 2012 and their conformity to the guidelines.
\end{abstract}

Material and Methods: Electronic prescription data of family physicians collected through Family Practice Information System were analyzed using Prescription Information System.

Results: Prescriptions with single-diagnosis of acute tonsillopharyngitis and their content were evaluated. It was seen that a total of 13.323 .611 prescriptions were given in that period, the agent most commonly found in these prescriptions were amoxicillin-clavulanate and cefuroxime and cefdinir followed that combination.

Conclusion: These results demonstrated beyond our personal observations that there is a frequent wide-spectrum and improper antimicrobial agent use under acute tonsillopharyngitis diagnosis in family practice in our country.

Keywords: Acute tonsillopharyngitis, antibiotics, amoxicillin-clavulanate, cefuroxime, cefdinir
Özet

Giriş: Antibiyotik kullanımının süt ve erken oyun çocukluğu döneminde en önemli nedeni akut otitis medya iken okul çocukluğu dönemi ve adölesan dönemde akut tonsillofarenjittir. Özellikle antimikrobiyal ajan kullanımının istenmeyen etkilerinin günümüzde daha ön plana çıktığı düşünüldüğünde, mutlak gerekli olduğunda ve mümkün olan en dar etkinlik yelpazesinde antimikrobiyal ajan kullanımının tercih edilmesi önem kazanmaktadır. Biz bu çalışmamızda, ülkemizde aile hekimleri tarafından 1 Ocak 2012 ve 31 Aralık 2012 tarihleri arasında akut tonsillofarenjit tanısı ile reçete edilen antimikrobiyal ajanların dağılımını ve bunların kılavuzlarla uyumluluğunu incelemek istedik.

Gereç ve Yöntemler: Aile hekimlerinin Aile Hekimliği Bilgi Sistemi (AHBS) aracılığıyla toplanan elektronik reçete verilerini, Reçete Bilgi Sistemi (RBS)'ni kullanarak inceledik.

Bulgular: Tek tanılı akut tonsillofarenjit reçetelerini ve içeriğindeki antibiyotikleri değerlendirdik. Bu dönemde toplam 13.323 .611 reçetenin sadece akut tonsillofarenjit tanısı ile oluşturulduğunu ve bu reçetelerde en çok bulunan ajanın amoksisilin-klavulanat olduğunu, sefuroksimin ve sefdinirin ise bunu takip ettiğini gördük.

Sonuç: Bu sonuçlar ile ülkemizde aile hekimliğinde tonsillofarenjit tanısı altında çok yaygın olarak geniş spektrumlu ve uygun olmayan antimikrobiyal ajan kullanımının olduğunu, kişisel gözlemlerin ötesinde göstermiş olduk.

Anahtar Kelimeler: Akut tonsillofarenjit, antibiyotik, amoksisilin-klavulanat, sefuroksim, sefdinir 
İşli et al.

Examination of the Prescriptions with

\section{Introduction}

Upper respiratory tract infections constitute the most frequentlyencountered reasons of antibiotic useinchildhood (1). Acute otitis media, acute sinusitis, and acute tonsillopharyngitis are the leading factors for antibiotic use in upper respiratory tract infections. During childhood, while acute otitis is the most frequent reason for antibiotic use from the first months of life until two-three years of age, acute tonsillopharyngitis becomes the primary factor for antibiotic use as of four-five years of age. As indicated in a report by the American Pediatric Academy aimed at reasonable antibiotic use in upper respiratory tract, antibiotics are prescribed in a vast majority of applications to outpatient clinics (2). While this number makes up nearly one of every 5 doctor visits, total antibiotic prescriptions is 50 million (2,3). All microorganisms which are agents of acute tonsillopharyngitis cause clinical pictures that ameliorate within its natural course $(1,4)$. Therefore, the aim in treatment is oriented at preventing acute rheumatoid fever which is a probable non-suppurative complication of Group A betahemolytic streptococcus rather than ameliorating the clinical picture $(1,3,5)$. To that end, the therapies recommended in either guidelines or reference materials are in the way of penicillin and amoxicillin, whose efficacy has not changed since their inception in clinical use, and macrolides or cephalosporin in case of penicillin allergy $(1,3-7)$. The evaluation of the contents of doctors' prescriptions contributes to the development of necessary regulations aimed at determining the state of antibiotic use and problems of unreasonable drug use. The aim of this study was to investigate the antibiotics prescribed in cases in whom acute tonsillopharyngitis was the only diagnosis established by family physicians.

\section{Materials and Metods}

In this study, the date range of January 1-December 31, 2012 that marked the period before the commencement of extensive education and studies regarding antibiotic use by Turkish Medicines and Medical Devices Agency of the Ministry of Health was evaluated. With the intention of evaluating the distribution of antibiotics prescribed in the diagnosis of acute tonsillopharyngitis, the electronic prescription data of the family physicians collected through Family Practice Information System (FPIS) in 2012 were analyzed retrospectively using Prescription Information System (PIS). All operation records of family physicians belonging to year 2012 were scanned through PIS which is a software that enables the prescription data to be analyzed and the prescribing habits of the physicians to be evaluated and give feedback to the physicians, and the number of prescriptions with acute tonsillopharyngitis was found. The number in item/box/cost parameters, Turkish Lira and percentage distributions of the antibiotics in prescriptions with only one diagnosis were determined. Moreover, these prescriptions were also evaluated in terms of the presence of injectable antibiotics. The 2010 retail sales prices of the drugs were used for cost calculation. ATC (Anatomical Therapeutic Chemical)classificationsystem (8) developedandrecommended by World Health Organization and where different codes are given according to the anatomic structure the drug has an effect over and to the chemical, pharmacological and therapeutic characteristics of the drug was used for drug classifications.

\section{Results}

While it was determined that a total of 201.929 .423 operations with diagnoses were performed through FPIS in 2012 by family physicians, it was seen that prescriptions were created for $55.63 \%$ of these operations (112.327.089 prescriptions).

13.323.611 of 112.327 .089 prescriptions by family physicians were formed with the diagnosis of acute tonsillopharyngitis, showing that $11.86 \%$ of all prescriptions had only one diagnosis, that is acute tonsillopharyngitis. It was detected that antibiotics were included in $79.58 \%$ (10.602.764 prescriptions) of 13.323 .611 prescriptions with the diagnosis of acute tonsillopharyngitis. It was seen that injectable antibiotics were prescribed in 4.69\% (624.584 prescriptions) of acute tonsillopharyngitis prescriptions with a single diagnosis.

When the drugs included in the prescriptions of family physicians were evaluated in general, it was found that the general item number of the drugs was 34.949.788. Antibiotics were included in $31.1 \%$ (10.868.939 items) and injectable antibiotics were included in $1.83 \%$ (639.569 items) of total drug items.

While $63.83 \%$ (232.025.179 TL) of total cost in prescriptions with acute tonsillopharyngitis diagnosis comprised antibiotics, the rate of injectable antibiotics in total cost was $3.62 \%$ (13.169.867 TL).

Antibiotics constituted $34.5 \%$ (13.104.971 boxes) of general drug box number which was 37.987 .478 and injectable antibiotics constituted $6.79 \%$ (2.578.471 boxes).

When antibiotic distributions were assessed as regards their frequency to be prescribed for acute tonsillopharyngitis, amoxicillin-clavulanate (42.98\%), cefuroxime (8.65\%) and cefdinir (6.85\%) were in the first place. In terms of economic data, it was understood that the highest cost in prescription cost distribution belonged to amoxicillin-clavulanate $(29.61 \%$ of total antibiotic cost), which was followed by cefinir (18.73\%) and cefuroxime (14.96\%).

When the distribution of general drugs in prescriptions with single diagnosis was assessed, amoxicillin-clavulanate ranked second with $13.37 \%$ and cefuroxime ranked eighth with $2.69 \%$ among the first ten drugs (Table 1). 
Table 1. Most frequently prescribed drugs by family physicians in Turkey in 2012

\begin{tabular}{|c|c|c|c|c|}
\hline $\begin{array}{l}\text { Rank among all } \\
\text { prescribed products }\end{array}$ & ATC 5 code & ATC 5 name & $\begin{array}{c}\text { Number of products in the } \\
\text { prescription }\end{array}$ & $\begin{array}{c}\text { Percentage of being } \\
\text { prescribed }\end{array}$ \\
\hline 1 & R05X & $\begin{array}{c}\text { Other drugs for the } \\
\text { common cold }\end{array}$ & 7.692 .348 & $22.01 \%$ \\
\hline 2 & J01CR02 & Amoxicillin-Clavulanate & 4.671 .135 & $13.37 \%$ \\
\hline 3 & N02BE01 & Paracetamol & 2.493 .602 & $7.13 \%$ \\
\hline 4 & A01AD02 & Benzydamine & 1.958 .519 & $5.6 \%$ \\
\hline 5 & M01AE01 & Ibuprofen & 1.866 .333 & $5.34 \%$ \\
\hline 6 & R05CB01 & Acetylcysteine & 1.366 .163 & $3.91 \%$ \\
\hline 7 & R05DB13 & Butamirate & 1.110 .700 & $3.18 \%$ \\
\hline 8 & J01DC02 & Cefuroxime & 939.702 & $2.69 \%$ \\
\hline 10 & R05DB27 & Levodropropizine & 845.071 & $2.42 \%$ \\
\hline
\end{tabular}

\section{Discussion}

Acute tonsillopharyngitis is one of the most frequently observed reasons of referral to a doctor in all age groups, particularly in childhood(1). Sore throat and dysphagia are the most commonly encountered complaints during the course of upper respiratory tract infections. The presence of pharynx and tonsil hyperemia and/or exudation with these complaints leads to the consideration of tonsillopharyngitis diagnosis. Microbiological agents causing tonsillopharyngitis are viral agents depending upon age groups. The only condition where antimicrobial treatment is indicated is streptococcal tonsillopharyngitis caused by group A beta hemolytic streptococcus. In fact, the aim in treatment in the clinical picture of tonsillopharyngitis caused by this agent is to prevent acute rheumatoid fever, one of the nonsuppurative complications (3-7). Being the most frequently observed bacterial pathogen causing acute tonsillitis, Group A streptococcus is responsible for $15-30 \%$ of all cases in childhood and $5-10 \%$ in adulthood and is the only clinical picture where antimicrobial treatment is definitely indicated (Table 2). When the prescriptions of family physicians were evaluated in this study, it was realized that a single acute tonsillopharyngitis diagnosis was established in nearly $12 \%$ (exact rate: $11.86 \%$ ) of all prescriptions. When not only the size of prescriptions with single diagnosis but also the size of prescriptions with more than one diagnosis including tonsillopharyngitis which were excluded from this study is taken into consideration, it would not be wrong to state that tonsillopharyngitis is one of the most frequent reason of referral to primary care and the most frequent cause of prescriptions.

The aim of treatment in Group A beta-hemolytic streptococcus tonsillitis is the prevention of suppurative and non-suppurative complications, the amelioration of clinical complaints, the provision of hasty return to school, kindergarten or work, and the prevention of transmission of the disease to persons in close contact. Antibiotics in the penicillin group is the first option in treatment. Penicillin resistance has not still been detected in Group A beta-hemolytic Streptococcus. The commencement of penicillin treatment within nine days after the start of symptoms prevents the development of acute rheumatoid fever. In this respect, while antibiotics should be used in $25-30 \%$ cases of tonsillopharyngitis in children and in less than $5 \%$ in adults, it is seen that the percentage of antibiotic prescription in our country is quite high. When the prescriptions of family physicians were evaluated, it was confirmed that antibiotics were included in about $80 \%$ of prescriptions with single diagnosis of tonsillopharyngitis and it was assessed

Table 2. Tonsillitis agent and age variations

\begin{tabular}{|l|c|c|}
\hline \multirow{2}{*}{ Agent } & \multicolumn{2}{|c|}{ Prevalans (\%) } \\
\hline Bakterial & In children & In adults \\
\hline GABHS & $30-40$ & $5-10$ \\
\hline $\begin{array}{c}\text { Grup C, G, or F } \\
\text { streptococci }\end{array}$ & $28-40$ & $5-9$ \\
\hline N. gonorrhoeae & $0-3$ & $0-18$ \\
\hline A. haemolyticum & $0-0.01$ & $0-0.01$ \\
\hline M. pneumoniae & $0-0.05$ & $0-10$ \\
\hline C. pneumoniae & $0-3$ & $0-10$ \\
\hline Viral & $0-3$ & $0-9$ \\
\hline Idiopathic & $15-40$ & $30-60$ \\
\hline
\end{tabular}


İşli et al.

Examination of the Prescriptions with

as a mark of presence of inappropriate use in the majority of prescriptions written in primary care.

Primary preference in treatment is oral penicillin or amoxicillin. The recommendation of parenteral antimicrobial agent use is limited only to benzathine penicillin $G(I M)$ and is opted to oral treatment if the patient will not tolerate or cannot adjust to oral treatment (1).

Patients allergic to penicillin may also be allergic to cephalosporin at a rate of $10 \%$ (8). If the allergy in these patients is not in the form of anaphylaxis, cephalosporin can be preferred (3-8). However, macrolides can be used in the possibility of anaphylaxis. Macrolide resistance in Group A beta-hemolytic streptococci is around 5\%. Therefore, macrolides should not be the first choice.

While the use of beta-lactamase inhibitor is not needed due to the fact that there is no resistance to penicillin in Group A beta-hemolytic streptococci or that beta-lactamase productions have not been detected, amoxicillin-clavulanate preference in the prescriptions of family physicians can be commented as an example of inappropriate use. When compared to amoxicillin, amoxicillin-clavulanate should not be used for acute tonsillopharyngitis due to excess side effects and unnecessary wide-spectrum (1,3-7).

Other antibiotics that can be used if penicillin allergy is not in the form of anaphylaxis include loracarbef, cefaclor, cefprozil, cefuroxime, axetil, ceftibuten, cefdinir, and cefpodoxime proxetil. Higher clinical and bacteriological eradication is ensured with oral cephalosporin in comparison to penicillin in acute streptococcal pharyngitis. However, its clinical significance has not been indicated (8).

Unreasonable antibiotic prescriptions and their use lead to the universal health problem, that is antibiotic resistance, which complicates treatment success of bacterial infections and gives rise to the inappropriate use of resources allocated for health. As in this study, the evaluation of the content of physicians' prescriptions may determine the state of antibiotic use and contribute to the necessary regulations and effective initiatives to be put forth in order to eliminate problems of unreasonable use. This study examining antibiotic prescriptions of all family physicians in all provinces of Turkey is significant in regard to its scope and to the fact that data belonging to the whole country has been put forth for the first time by excluding periodic differences. On the other hand, the evaluation of antibiotic use through prescriptions with frequently encountered acute tonsillopharyngitis is of vital importance in respect to minimizing probable disarray that multiple diagnoses could cause.
Ethics Committee Approval: Ethics committee approval has not been obtained for this study.

Informed Consent: Anonymous data were used for this study.

Peer-review: It is peer-reviewed article.

Author Contributions: Author Contributors: Fatma İsli, Mesil Aksoy and Ali Alkan have contributed to the the study by providing, analysis and interpretation of the data. Ateş Kara has contributed to the study by supporting the literature and writing the article.

Conflict of Interest: There is no conflict of interest in this study.

Financial Disclosure: No financial support was received for this study.

\section{References}

1. Cherry JD. Pharyngitis (Pharyngitis, tonsillitis, tonsillopharyngitis, and nasopharyngitis). In: Cherry JD, Harrison GJ, Kaplan SL, Steinbach WJ, Hotez PJ (eds). Feigin and Cherry's Textbook of Pediatric Infectious Diseases, $7^{\text {th }}$ ed. Philadelphia: Elsevier, Saunders, 2014:156-65.

2. https://www.aap.org/en-us/about-the-aap/aap-press-room/ pages/American-Academy-of-Pediatrics-Advises-Physicians-to-UseAntibiotics-Judiciously.aspx (Erişim tarihi: Ocak 2017).

3. Shulman ST, Bisno AL, Clegg HW, et al. Clinical Practice Guideline for the Diagnosis and Management of Group A Streptococcal Pharyngitis: 2012 Update by the Infectious Diseases Society of America. Clin Infect Dis 2012;55:1279-82. [CrossRef]

4. National Institute for Health and Clinical Excellence (NICE): Prescribing oral antibiotics for self limiting respiratory tract infections in adults and children in primary care 2008. (Clinical guideline 69) London: NICE, 2008.

5. Bisno AL, Gerber MA, Gwaltney JM, Kaplan EL, Schwartz RH. Practice guideline for the diagnosis and management of group A streptococcal pharyngitis. Clin Infect Dis 2002;35:113-25.[CrossRef]

6. Reqoli M, Chiappini E, Bonsiqnori F, Galli L, Martino M. Update on the management of acute pharyngitis in children. Ital J Pediatr 2011;37:10. [CrossRef]

7. Pichichero ME. A review of evidence supporting the American Academy of Pediatrics recommendation for prescribing cephalosporin antibiotics for penicillin-allergic patients. Pediatrics 2005;115:1048-5. [CrossRef]

8. https://www.whocc.no/atc_ddd_index/(Erişim tarihi: Aralık 2016). 